\title{
The Model Of Performance Based Evaluation Of Civil Servants In Vietnam
}

\author{
PhD. Dao Thi Thanh Thuy \\ Vietnam Youth Academy
}

\begin{abstract}
The performance-based evaluation and payroll systems for government employees formed in the late $1980 \mathrm{~s}$ in many developed countries. Survey results on strategic human resource management in the 29 OECD countries show that these systems are applied based on individual performance evaluation and one third of OECD countries have developed a performance management system for senior civil servants. This article introduces legal regulations and the application of the performance-based evaluation model for civil servants in Vietnam. The author uses analytical method to justify the significant implications that the research poses in the improvement of the civil servant management regime in Vietnam. The author focuses on researching and clarifying status of the evaluation work after the Law on Cadres and Civil Servants came into force in 2010, points out the shortcomings and causes to formulate renovation and improvement proposals. At the same time, expert method is used by the author to seek advice from managers and experts on human resources management and related issues, identifying the prerequisites for applying the performance-based evaluation system in Vietnam. The author also uses sociological survey method, questionnaire form for civil servants working in four-level authorities. At central level, there are Ministries, including the Ministry of Home Affairs, the Ministry of Health, the Ministry of Labor, Invalids and Social Affairs, the Ministry of Finance, the Ministry of Justice, the Ministry of Agriculture and Rural Development, Ministry of Natural Resources and Environment, the Office of the Government, the State Bank, the State Audit; Localities include provinces: Hai Duong, Ninh Binh, Bac Giang, Hung Yen, Cao Bang, Quang Ninh, Quang Nam, Hue, Daklak, Daknong, and cities under central control: Ha Noi, Hai Phong. The surveyed localities are selected on the basis of ensuring representative for localities with urban and rural characteristics; delta and mountainous areas. Results of this survey support the analysis and evaluation of the situation part.
\end{abstract}

Key word: civil servant evaluation, performance evaluation

\section{INTRODUCTION}

In the management and evaluation of civil servants, to measure and classify civil servants there are several approaches based on theories in the world over different periods, which are as follows:

First, evaluating civil servants by inputs is a way of assessing people in the organization based on what is available to determine their ability to fulfill their tasks in the future (degrees, certificates, age, gender, experience ...)[3]

Second, evaluating civil servants by their process of work performance is defined as activities to transform inputs into outputs to achieve the desired outcomes. Civil servants evaluation in this way can be expressed through the time spent doing the work, the way it is performed, the standards of behaviors and attitudes while working, focusing on strict adherence to the regulations of State agencies and laws in association with the procedure control mechanism. [3]

Third, evaluating civil servants by performance results. The result is the final product of the process by which the civil servant performs the work. This approach is linked to a 
performance-based management ${ }^{1}$ and/or results-based management system ${ }^{2}$ in the context the countries of the Organization for Economic Co-operation and Development (OECD) ${ }^{3}$ implement strategies for improving operational effectiveness under the pressure of the economic crisis leading to budget deficit. [3]

Evaluating civil servants by performance results is very significant to the civil servant management system. For civil servant management agency, it is an important way to manage human resource. Based on the specific criteria for measuring work performance, civil servant evaluation by performance results has important implications for civil servant management agencies such as:

Strengthening control of work performance results; enhancing edictability of operational risks; ensuring impartiality and objectiveness in rewarding, payment, appointment, rotation or termination on the basis of specific measurement criteria; Identifying training needs and potential development of civil servants to prepare succession planning; Linking and mobilizing strengths of the organization with its human resource to achieve goals; Monitoring and evaluating the implementation progress compared to the set objectives; Identifying the shortcomings to take timely adjusments; Allowing the implementation of activities to improve the performance quality of civil servants ... [2]

\section{SPECIFIC CASE}

The evaluation of civil servants by performance results in the Party agencies is currently based on the following documents:

- Regulation on evaluation of cadres and civil servants issued in conjunction with Decision No. 286-QD / TW dated 8 February 2010 of the The Political Bureau (Politburo)

- The Law on Cadres and Civil Servants 2008 took effect from January 1, 2010, Section 6 with 4 Articles from Article 55 to 58 stipulating the evaluation of civil servants.

- Decree No. 24/2010 / ND - CP dated March 15, 2010 regulating the recruitment, employment and management of civil servants (amended and supplemented by Decree No. 93/2010 / ND-CP dated August 31, 2010).

- The Government's Decree No. 56/2015 / ND-CP of June 9, 2015 on the evaluation and classification of cadres, civil servants and officials took effect on August 1, 2015 (amended and supplemented by Decree No. 88/2017 / ND-CP dated July 27, 2017).

Civil servant evaluation according to the Law on Cadres and civil servants distinguishes between cadres and civil servants. For civil servants, the evaluation shall be based on the following six basic criteria (Article 56): Observance of the line and policies of the Party and laws of the State; Political qualities, ethics, lifestyle and working style and manners; Specialized or professional capabilities and qualifications; Task performance progress and results; Sense of responsibility and collaboration in work; Attitude in serving the people. However, the implementation of Decree 24 and Decree 93 shows that these criteria are scattered and not focused on work performance to measure actual results, it makes the application of resultsbased evaluation more difficult.

To overcome such weaknesses, the Government's Decree No. 56/2015 / ND-CP of June 9, 2015 on the evaluation and classification of cadres, civil servants and public employees determines the evaluation and classification of civil servants by work year, which is carried out in December every year (Article 5). Evaluation results are an important basis for arranging, employing, appointing, terminating, rotating, rewarding, disciplining and implementing other policies towards civil servants. The results of evaluation and classification of public employees shall comply with the provisions in Clause 3, Article 29 and Clause 3, Article 58 of the Law on 
Cadres and Civil Servants (Clauses 1 and 2, Article 6). The contents of civil servant evaluation comply with the provisions in Clauses 1 and 2, Article 56 of the Law on Cadres and Civil Servants.

Decree No. 56/2015/ND-CP defines the principles for evaluating and classifying civil servants (Article 3) as follows: (1) Ensuring proper authority: cadres are evaluated by the authorized levels; civil servants are evaluated by the heads of agencies, organizations or units. At any level, the evaluators shall simultaneously perform the classification and be responsible for their decisions; (2) The evaluation must be based on the responsibilities, tasks assigned and performance results. The evaluation should clarify strengths, weaknesses, shortcomings and limitations on the quality, capability and qualifications of civil servants; (3) ensuring objectivity, fairness, accuracy, without repression, bias, formalism;

(4) The evaluation and classification of leading and managerial civil servants must be based on the results of activities of their own agency, organization or unit. The level of their task completion must not be ranked higher than that of the agency, organization or unit. The evaluation of civil servants is based on their duties, ethics, behavioral conduct and service culture and what they are not allowed to do as regulated in the Law on Cadres and Civil Servants; Standards of civil servant categories, managerial leadership positions; Tasks assigned under annual programs and work plans (Clause 2, Article 4 of Decree 56).

Regarding authority and responsibility for evaluating and classifying civil servants: The heads shall directly evaluate and classify their deputies and civil servants, take responsibility for evaluation \& classification results; The heads of agencies, organizations and units are evaluaed by the heads of higher-level agencies and the evaluation and classification results are under responsibility of these agencies (Article 16).

Simultaneously, based on classification of the results of civil servant evaluation under the provisions of the Law on cadres and civil servants, Decree 56 specifies the criteria for four levels of performance results including: Excellent task completion, good task completion, task completion but limited competence and task incompletion. In which, civil servants who achieve excellent completion task must fulfill $100 \%$ of their tasks under annual programs and plans, ahead of schedule, with quality and efficiency; promptly and qualified, effective completion of the extraordinary tasks; Having at least 01 scientific work, project, theme or initiative that have been applied effectively in public activities of the agency, organization or unit and recognized by competent authority (Article 18).

The performance result is a key element in the evaluation of individual civil servants. The Decree also clarifies that the evaluation results will be used to apply to future policy and mechanisms. Evaluation criteria are also important to be applied throughout the system, with determined percentage to measure the levels of task completion. The requirements and criteria for the excellent task completion are significantly hightened, forcing civil servants to make greater efforts to achieve this level of evaluation. The specification of this criterion overcomes the limitation of the fact that the proportion of civil servants with excellent task completion is high but the performance of the functions and tasks of the agency is inadequate.

\section{PRINCIPLES FOR ASSESSING CIVIL SERVANTS BY WORK RESULTS}

In government agencies, there are different levels of result evaluation, such as evaluation of system performance, individual agency performance and individual civil servant performance. These levels are closely interrelated, interacted with one another. To ensure the effectiveness 
of individual evaluation to faciliate agency and system, it is important to ensure that the following key principles are met:

- The performance results of the individual must clearly reflect the organization's performance;

- The individual's work performance must be appropriate and reflect the nature of the work position.

- The individual's work performance must be comprehensive, covering the overall performance of the work on different aspects.

- The individual's work performance must be reliable, reflecting the devotation by authentic information system and recognized by others.

- The individual's work performance must be measurable for comparison to others.

\section{PRACTICAL IMPLEMENTATION OF THE MODEL IN VIETNAM}

On the basis of the Law on Cadres and Civil Servants and guiding documents of the Ministry of Home Affairs, Hanoi City has implemented the evaluation work by Official Letter No. 2888 /SNV-VP dated 9 Dec 2013 of Ha Noi's Department of Home Affairs guiding the evaluation of cadres, civil servants, public employees in 2013;

Da Nang People's Committee issued Decision No. 7786/QD-UBND dated November 18, 2006 detailing regulations on the evaluation of cadres and civil servants annually and has implemented results-based evaluation model in Official Letter No. 908/BNV- CCHC from July 2012, piloted with 600 officials of 10 administrative units ( 7 departments and 3 districts), accounting for $1 / 3$ of the total number of civil servants in the city, divided into 4 groups: head of division and equivalent positions, department's deputy directors and the equivalent, civil servants who perform general consulation and advisory work, and civil servants who perform support and operational work. Based on the initial results, the People's Committee continued to issue Official Letter No. 2035/UBND-NCPC dated March 18, 2013 to implement this evaluation model. The evaluation is monthly implemented on the online software. The implementation in the two above cities has shown significant changes in the application of civil servant evaluation method in public administrative agencies.

In Ha Noi, the work standardization method for civil servants is classified into four main groups, including: (1) Performance results of assigned tasks; (2) Political qualities, execution of the Party's lines, guidelines and policies, and the State's laws; (3) Moral qualities, lifestyles, style and manner of work; (4) Organizational discipline. The first group of standards for professional civil servants and leadership managerial civil servants is specified as follows: 
Table 1. Performance evaluation standards for civil servants of Ha Noi city

\begin{tabular}{|c|c|c|c|}
\hline Standard & Object & Specific standard & Explaination \\
\hline \multirow{5}{*}{$\begin{array}{l}\text { Performa } \\
\text { nce of } \\
\text { assigned } \\
\text { tasks }\end{array}$} & \multirow{4}{*}{$\begin{array}{l}\text { Specialized/ } \\
\text { professional } \\
\text { civil } \\
\text { servants }\end{array}$} & $\begin{array}{l}\text { 1. The level of performing tasks } \\
\text { assigned in the year (according to the } \\
\text { quantity, quality, progress and work } \\
\text { efficiency in each position and time, } \\
\text { including regular and extraordinary } \\
\text { tasks) }\end{array}$ & \\
\hline & & \multirow{2}{*}{$\begin{array}{l}\text { 2. Results of the implementation of the } \\
\text { Directive No. } 01 \text { / CT-UBND dated } 04 \\
\text { January } 2013 \text { of the Chairman of the } \\
\text { City People's Committee on the } \\
\text { implementation of "Administrative } \\
\text { discipline year - 2013" }\end{array}$} & $\begin{array}{l}2.1 \text { The spirit/attitude and responsibility of } \\
\text { individuals in performing assigned tasks to } \\
\text { improve work quality and efficiency }\end{array}$ \\
\hline & & & $\begin{array}{l}\text { 2.2. Results of work cooperation with } \\
\text { colleagues in the agency; the attitude of } \\
\text { serving the people }\end{array}$ \\
\hline & & $\begin{array}{l}\text { 3. The self-learning spirit to improve } \\
\text { capability, professional qualifications } \\
\text { and skills to meet the requirements of } \\
\text { job position, assigned tasks }\end{array}$ & \\
\hline & \multirow{6}{*}{$\begin{array}{l}\text { Managerial } \\
\text { civil } \\
\text { servants }\end{array}$} & $\begin{array}{l}\text { 1. Leadership and management } \\
\text { competence; the ability to gather and } \\
\text { unite civil servants, the level of } \\
\text { completion of assigned tasks } \\
\text { (expressed in quantity, quality, } \\
\text { progress and efficiency of each position } \\
\text { and time, including regular and } \\
\text { irregular tasks) }\end{array}$ & \\
\hline & & \multirow{3}{*}{$\begin{array}{l}\text { 2. Results of the implementation of the } \\
\text { Directive No. } 01 \text { / CT-UBND dated } 04 \\
\text { January } 2013 \text { of the Chairman of the } \\
\text { City People's Committee on the } \\
\text { implementation of " Administrative } \\
\text { principle Year - 2013" }\end{array}$} & $\begin{array}{l}\text { 2.1. The results of the assignment of specific } \\
\text { responsibilities to each department, division, } \\
\text { section.., each cadre, civil servant and } \\
\text { employee, without duplication or } \\
\text { overlapping }\end{array}$ \\
\hline & & & $\begin{array}{l}\text { 2.2. The results of the review and finalization } \\
\text { of documents for issuance or proposal to } \\
\text { competent authorities for issuance of } \\
\text { internal rules, working regulations and } \\
\text { procedures for settling affairs of agencies in } \\
\text { order to ensure uniformity with the current } \\
\text { law regulations; To well organize the } \\
\text { implementation of democrative regulations } \\
\text { at grassroots level, set regulations on public } \\
\text { service culture at agencies and units }\end{array}$ \\
\hline & & & $\begin{array}{l}\text { 2.3. Results of work cooperation with } \\
\text { departments, units in the agencies or the } \\
\text { related agencies; morale and attitude to } \\
\text { serve the people }\end{array}$ \\
\hline & & $\begin{array}{l}\text { 3. The performance level of tasks } \\
\text { assigned in the year and operational } \\
\text { results of the agencies, organizations or } \\
\text { units }\end{array}$ & \\
\hline & & $\begin{array}{l}\text { 4. The self-learning spirit to enhance } \\
\text { capability, professional qualifications } \\
\text { to meet the requirements of work } \\
\text { position, tasks assigned }\end{array}$ & \\
\hline
\end{tabular}

Source: Summary based on Ha Noi civil servant evaluation scale in 2013 
The above evaluation criteria of Ha Noi are measured by the 100-points marking method. Each rating scale is divided into 4 levels: good/fair/average/weak as the basis for marking. For example, for criterion of group 4 (sense of discipline) the maximum is 20 points. In which, the compliance of rules and working regulations of agencies and units; preservation of the public service culture; ensuring working time is marked 5 points but divided into levels as follows: good ( 5 points); fair ( 4 points); average ( 3 points) and weak ( 0 points).

Table 2. Scale of civil servant evaluation in Ha Noi

\begin{tabular}{|c|c|c|c|c|c|c|c|c|c|c|c|c|c|}
\hline \multirow{4}{*}{ Object } & \multicolumn{12}{|c|}{ Maximum point } & \multirow{4}{*}{$\begin{array}{l}\text { Total } \\
\text { points }\end{array}$} \\
\hline & \multirow{2}{*}{\multicolumn{4}{|c|}{$\begin{array}{c}(1) \\
\text { Performance result of assigned } \\
\text { tasks }\end{array}$}} & \multirow{2}{*}{\multicolumn{2}{|c|}{$\begin{array}{c}\text { (2) } \\
\text { Political } \\
\text { qualities, } \\
\text { compliance with } \\
\text { the Party's } \\
\text { policies, the } \\
\text { State's laws } \\
10\end{array}$}} & \multicolumn{3}{|c|}{$\begin{array}{c}\text { (3) } \\
\text { Moral qualities, lifestyle, } \\
\text { manner and work style }\end{array}$} & \multicolumn{3}{|c|}{$\begin{array}{c}\text { (4) } \\
\text { Organizational awareness } \\
\text { and } \\
\text { discipline }\end{array}$} & \\
\hline & & & & & & & \multicolumn{3}{|c|}{10} & \multicolumn{3}{|c|}{20} & \\
\hline & $\begin{array}{l}\text { Work } \\
\text { result }\end{array}$ & $\begin{array}{c}\text { Results of } \\
\text { the } \\
\text { implementat } \\
\text { ion of } \\
\text { Directive } \\
\text { No. } 01 / \text { CT- } \\
\text { UBND }\end{array}$ & $\begin{array}{c}\text { Improvi } \\
\text { ng } \\
\text { capabilit } \\
\text { y and } \\
\text { level }\end{array}$ & $\begin{array}{l}\text { Leader } \\
\text { ship } \\
\text { compet } \\
\text { ence }\end{array}$ & $\begin{array}{l}\text { Political } \\
\text { thought }\end{array}$ & $\begin{array}{l}\text { Complian } \\
\text { ce with } \\
\text { guideline } \\
\text { s, policies }\end{array}$ & $\begin{array}{l}\text { Maintai } \\
\text { ning } \\
\text { ethics } \\
\text { and } \\
\text { lifestyle }\end{array}$ & $\begin{array}{c}\text { Honesty, } \\
\text { solidarity, } \\
\text { criticism } \\
\text { and self- } \\
\text { criticism }\end{array}$ & $\begin{array}{c}\text { The } \\
\text { attitud } \\
\text { e of } \\
\text { serving } \\
\text { the } \\
\text { people }\end{array}$ & $\begin{array}{l}\text { Complia } \\
\text { nce with } \\
\text { internal } \\
\text { rules } \\
\text { and } \\
\text { regulati } \\
\text { ons }\end{array}$ & $\begin{array}{l}\text { Complia } \\
\text { nce with } \\
\text { the } \\
\text { assignm } \\
\text { ent of } \\
\text { the } \\
\text { organiza } \\
\text { tion }\end{array}$ & $\begin{array}{l}\text { The spirit } \\
\text { of } \\
\text { cooperati } \\
\text { on, } \\
\text { improvin } \\
\text { g } \\
\text { qualificati } \\
\text { ons }\end{array}$ & \\
\hline $\begin{array}{l}\text { Specialized } \\
\text { civil } \\
\text { servant }\end{array}$ & 30 & 25 & 5 & & 5 & 5 & 4 & 3 & 3 & 5 & 5 & 10 & 100 \\
\hline $\begin{array}{l}\text { Managerial } \\
\text { civil } \\
\text { servants }\end{array}$ & 10 & 25 & 5 & 20 & 5 & 5 & 4 & 3 & 3 & 5 & 5 & 10 & 100 \\
\hline
\end{tabular}

Source: Summary based on Ha Noi civil servant evaluation scale in 2013

In Da Nang, with the method of marking (100 points), in the criteria prescribed by the Law on Cadres and Civil Servants, the criterion "Observance of the line and policies of the Party and laws of the State; Political qualities, ethics, lifestyle and working style and manners" is marked 10 points; the criteria "Task performance progress and results; Attitude in serving the people" is 20 points; and the criterion "Specialized or professional capabilities and qualifications" is 70 points. There is also marking criteria to civil servants with good performance and negative points for those with under performance. 
Table 3. Scale of civil servant evaluation in Da Nang City

\begin{tabular}{|c|c|c|c|c|c|c|c|c|c|c|c|c|c|}
\hline \multirow[b]{2}{*}{ Object } & \multicolumn{6}{|c|}{ Self evaluation } & \multicolumn{6}{|c|}{ Bonus points } & \multirow[b]{2}{*}{ Total } \\
\hline & $\begin{array}{l}\text { Regu- } \\
\text { lation } \\
\text { comp- } \\
\text { liance }\end{array}$ & $\begin{array}{l}\text { Attitude, } \\
\text { respons } \\
\text {-ibility }\end{array}$ & $\begin{array}{c}\text { Perfor- } \\
\text { mance } \\
\text { effective- } \\
\text { ness }\end{array}$ & $\begin{array}{l}\text { Perfor- } \\
\text { mance } \\
\text { time }\end{array}$ & $\begin{array}{l}\text { Leader- } \\
\text { ship } \\
\text { compe- } \\
\text { tence }\end{array}$ & Subtotal & $\begin{array}{l}\text { Regulation } \\
\text { comp- } \\
\text { liance }\end{array}$ & $\begin{array}{l}\text { Attitude, } \\
\text { respon- } \\
\text { sibility }\end{array}$ & $\begin{array}{l}\text { Perfor- } \\
\text { mance } \\
\text { effect- } \\
\text { tiveness }\end{array}$ & $\begin{array}{c}\text { Perfor- } \\
\text { mance } \\
\text { time }\end{array}$ & $\begin{array}{l}\text { Leadership } \\
\text { com- } \\
\text { petence }\end{array}$ & Subtotal & \\
\hline $\begin{array}{l}\text { Civil } \\
\text { Servants } \\
\text { who are } \\
\text { Supporting } \\
\text { staff }\end{array}$ & 8 & 18 & 35 & 21 & & 82 & 2 & 2 & 10 & 4 & & 18 & 100 \\
\hline $\begin{array}{l}\text { Civil } \\
\text { Servants } \\
\text { who } \\
\text { perform } \\
\text { Advisory } \\
\text { tasks and } \\
\text { general } \\
\text { affairs } \\
\end{array}$ & 8 & 18 & 40 & 16 & & 82 & 2 & 2 & 10 & 4 & & 18 & 100 \\
\hline $\begin{array}{l}\text { Head of } \\
\text { section }\end{array}$ & 8 & 18 & 35 & 11 & 10 & 82 & 2 & 2 & 10 & 2 & 2 & 18 & 100 \\
\hline $\begin{array}{l}\text { Department } \\
\text { Vice- } \\
\text { Director }\end{array}$ & 8 & 18 & 25 & 8 & 23 & 82 & 2 & 2 & 10 & 2 & 2 & 18 & 100 \\
\hline
\end{tabular}

Source: Summary based on work performance evaluation forms for civil servants of Da Nang City

At the same time, the monthly evaluation on online software helps to ensure the objectivity, fairness and transparency as the software will sum up the points and result the level of task completion as prescribed in the Law on Cadres and Civil Servants. The software will automatically announce results of the evaluation and information after the Evaluation Board reviews the highly different points between the direct supervisors, civil servants and those who have long time off in the month that affects the work ... and select individuals with excellent results.

Over 2,000 employees have logged in, used the software; 35,000 working tasks have been declared and input in the system. In 2013, the proportion of administrative civil servants in departments, sections, districts was 4.5 times lower than in 2012, indicating a significant change from the previous classification by votes. The increase in proportion of under performance civil servants proves the initial success in working result classification of civil servants and employees in the agencies and units.

\section{EVALUATION OF THE MODEL}

actual evaluation of civil servants in Ha Noi, Da Nang shows that the renewal of civil servant evaluation method associated with service performance has achieved the following achievements: Forming general legal framework for the evaluation of civil servants; Being proactive in innovating civil servant evaluation model in localities; Highlighting the performance result in civil servant evaluation and the results have made the classification of civi servant's work devotation more clearly.

In addition to the positive changes, the evaluation of civil servants under the Law on Cadres and Civil servants reveals the following limitations:

\section{Firstly, the evaluation criteria still do not really focus on the performance of individual civil servants}

Six evaluation criteria of Article 56 include: (1) Observance of the line and policies of the Party and laws of the State; (2) Political qualities, ethics, lifestyle and working style and manners; (3) Specialized or professional capabilities and qualifications; (4) Task performance progress and 
results; (5) Sense of responsibility and collaboration in work; (6) Attitude in serving the people. In particular, the performance of the task only accounts for $2 / 6$ criteria (criterion 4 and 5), no weight or different rate when evaluating. Criteria mainly focus on personality characteristics and compliance with general regulations rather than specific work objectives; Too emphasizes that civil servants must obey obligations rather than creatively fulfill or exceed personal goals associated with the goals of the unit or agency.

According to the author's survey, the question "Which of the current civil servant evaluation results highlights the following?" The six options are: (1) Performance result; (2) Task performance progress; (3) Political qualities; (4) Ethics, lifestyle, spirit of cooperation; (5) Compliance with regulations; (6) Personal Achievement. In particular, respondents can choose from a variety of options. Through the survey, the results are as follows:

Table 4. Results of the survey on the most focused content through civil servant evaluation

\begin{tabular}{|c|c|c|c|c|}
\hline Contents & Central level & $\begin{array}{l}\text { Provincial } \\
\text { level }\end{array}$ & $\begin{array}{c}\text { District } \\
\text { level }\end{array}$ & $\begin{array}{c}\text { Commune } \\
\text { level }\end{array}$ \\
\hline Completion of task & 76.00 & 76.92 & 68.18 & 78.88 \\
\hline $\begin{array}{l}\text { Political qualities, ethics, lifestyle and } \\
\text { working style and manners }\end{array}$ & 98.00 & 53.84 & 37.50 & 54.03 \\
\hline $\begin{array}{l}\text { Compliance with regulations of the the } \\
\text { State/organization; task performance } \\
\text { process }\end{array}$ & 72.00 & 32.05 & 36.36 & 38.50 \\
\hline Personal achievements & 37.00 & 33.33 & 23.86 & 24.84 \\
\hline
\end{tabular}

Source: Survey data of the author

With the above results, it can be seen that civil servants at all levels have been fairly evaluated. There is no big difference between the criteria and the evaluation results are closely linked to the ethical evaluation, lifestyle and rule observance. In which, the evaluation of civil servants in association with the completion results takes the highest percentage. This is also an important orientation in renovating the civil servant evaluation in the view of the Law on cadres and civil servants. The problem is that the percentage of evaluation result that focuses on personal achievement is relatively low.

Obviously, this is a huge contradiction when task completion is a factor of concern but it is not associated with individual achievement. This is in line with the statement in the Summary report on the implementation of Ordinance on cadres and civil servants from 1998 to 2008 "method, content and criteria of evaluation on cadres, civil servants have not focused on work effectiveness and result.... The proportion of civil servants rated as excellent, fair, average, and poor has not been linked to the results and task completion level of the agency or unit. The situation "retreat to avoid a conflict" is still common in evaluation so it is not clear to define the well-performed civil servants with the underperformed ones". Thus, the result-focused evaluation of civil servants meets difficulties due to inadequacies from the criteria system.

\section{Secondly, names of the criteria are not consistent}

According to Article 56 of the Law on Cadres and Civil Servants 2008, among the 6 criteria for evaluating civil servants, if criteria 3, 4, 5, 6 are relatively clear and consistent in terms of names, criteria 1 and 2 are still duplicated and unconfirmed leading to difficulties in actual evaluation. In which, criterion 1 is "Observance of the line and policies of the Party and laws of the State"; The second criterion is evaluation through "Political qualities, ethics, lifestyle and 
working style and manners". The political qualities of civil servants show their loyalty to their career, helping them to overcome difficulties, challenges and temptations to form the bravery of daring to do, daring to take responsibilities before the law.

The problem is that what is the different between the political aspect of criterion $2^{4}$ and criterion 1, and in fact, when conducting the evaluation, the political quality is often expressed through the "perception" of the subject, which is not linked to work performance. This leads to a staff with very good moral qualities has his work incompleted or completed on average level and vice versa. Therefore, the use of the names of the criteria 1 and 2 is not generalized to unify the way of implementation.

\section{Third, some criteria are difficult for measurement}

With the criterion "Political qualities, ethics, lifestyle and working style and manners" (Criterion No. 2 of the Law on Cadres and Civil Servants), the content of "political qualities" here coincides with criteria No. 1, so these two groups are in-distinguishable and quantifiable, which will often be ignored when conducting the evaluation. In terms of "Political qualities, ethics, lifestyle and working style and manners", it can be understood as follows:

1) The ethics are associated with the implementation of the principles and norms of work on the basis of law and agency regulations. If not clearly defined, it will be confused with the personal ethics in daily life and used as a basis for evaluating work performance;

2) Lifestyle is reflected in the relations between civil servants and colleagues, the cooperation and collaboration spirit between civil servants and related organizations and between the civil servants' behavior and organizations, citizens in the society. These expressions are not always clearly identifiable but are sometimes reflected through public opinion, the people's opinions by praise or criticism;

3) Working style and manners, ethics of civil servants are evaluated through behaviors and attitudes of civil servants in performing their duties, including the following: compliance with the provisions of law; communication language, guestures... to communication objects;

However, these criteria are very difficult to measure accurately, mainly based on the perception of the evaluation subject. The undefined standards to evaluate qualities will lead to maximum points given to civil servants in this group of criteria, becoming the "life buoy" of the total score for the underperformed person. Criteria are difficult to quantify, for example, for the criteria of spirit and attitude to serve the people, the role of citizens in evaluating civil servants should be documented, institutionalized to take effective and become a part of the overall ratio of public servant evaluation.

The above limitations are due to the following reasons:

Firstly, the system of jobs and positions has not been completed. The determination of work position will be the basis for the competent agencies, organizations and units to carry out the evaluation accurately, objectively and fairly for civil servants. The job description and/or role description sheet is a quantitative measure of the quality of civil servants that is not based on willingness or through other factors. However, the job description and position-based system has not been completed, so it is not possible to develop consistent measurement tools.

Second, there is a lack of formal commitments between the subject and the object of management as the basis for the evaluation. This reflects the fact that the civil servants themselves evaluate their results and do not remember all the work/tasks they have done. This can be done very easily if there are archives such as work logs, work plans. 
Thirdly, the evaluation results are not directly linked to job rearrangement and the application of policy and mechanisms to civil servants. It can be seen that the current evaluation results are mainly used to classify civil servants at the end of the working year, which is not a direct basis for planning, appointment, training and retraining decisions, development plans and the dismissal of underperformed civil servants.

As a result, the results of specific civil servant evaluations are not really linked to the development of civil servants, which makes them satisfied with the need to develop and assert themselves. The salary regime in state agencies is based on grades and categories; focusing on experience and qualifications of civil servants expressed through diplomas. Those of the same grade and category get the same salary despite their different dedication and performance. There is no competition for benefits, which discourages the evaluators to be responsible for evaluation contents. Since then, the process of evaluation has become increasingly less critical to minimize shortcomings of colleagues. This is the reason why the number of "advanced labors" title occupies such a large proportion in state agencies over the past time.

\section{CONCLUSION}

With the well-defined rules of civil servant evaluation in Vietnam, there is much to be done in order to have a management approach that is able to promote qualified people and eliminate the weak. If there is no basis for performance evaluation, it is difficult to highligh the result factor in order to apply related policies. In order to effectively carry out the evaluation of civil servants, the following prerequisites must be taken into account:

- Results-based evaluation system should be linked with the development strategy of the organization. Hence, gradually integrating into the system, making members of the system to socialized, adapt, trust, and welcome. This is the basis to form the evaluation of individuals by work results, achievements, dedication.

- The results-based evaluation system requires active and responsible participation of all stakeholders in the organization, including the head and staff to be able to formulate evaluation criteria with high consensus and agreement.

- The results-based evaluation system should ensure the consistency of the whole system so that the evaluation can be standardized and compare results among individuals. Therefore, the role of leaders, specialists, and officers of the organization will play a decisive role in the design, development and improvement of the system.

- Results-based systems need to focus on performance rather than on other factors. Where there are many results, there must be indicators for measurement, reflecting the end result.

- The results-based evaluation system should provide valuable, reliable and practical information for the leader to use for assigning, arranging, rearranging the agency's policies such as results-base payroll, planning, appointing, and personal developement.

\section{References}

Tran Kim Dung (2011): "Human Resource Management", 8 $8^{\text {th }}$ Edition, General Publishing House of Ho Chi Minh City.

Nguyen Thi Hong Hai (2013): "Performance-Based Management of public service" Labor Publishing House, Ha Noi, Viet Nam

Dao Thi Thanh Thuy (2016): Civil servant evaluation by public service performance result, PhD thesis on public administration management, National Academy of Public Administration, Ha Noi, Vietnam.

National Assembly: Law on Cadres and Civil Servants 2008

Asian Development Bank (2003): Serving and Maintaining - Improving Public Administration in a Competitive World, National Political Publishing House, Ha Noi, Vietnam.

Jody Zall Kusek, Ray C. Rist (2005): Ten Steps to a Result-Based Monitoring and Evaluation System, Culture and 
Information Publishing House;

Resolution No. 30c/2011/NQ-CP dated 08 Nov 2011 of the Government promulgating the overall program of state administrative reform in the period 2011-2020

Danang People's Committee: Official Letter No. 2035 / UBND - NCPC dated March 18, 2013 on evaluation of working results of civil servants in Da Nang city, Da Nang

Department of Home Affairs of Da Nang City (2013): Report No. 1032/SNV - CBCC dated 10 June /2013 on classification of civil servants 2012, Da Nang;

Department of Home Affairs of Da Nang City (2013): Report on reviewing results of work performance in Da Nang city in 2013, Da Nang;

Ha Noi Department of Home Affairs: Official Letter No. 2888 / SNV - VP dated 9 Dec 2013 on evaluation of officials, civil servants, public employees and laborers in 2013, Ha Noi;

Dick Grote (2002): The Performance appraisal question anhd answer book: a survival guide for managers;

Abu-Doleh, J. \& Weir, D. (2007). Dimensions of performance appraisal systems in Jordanian private and public organizations. International Journal of Human Resource Management;

OECD (2005), “Performance - Related Pay Policies for Government Employees”, OECD Publishing, Paris;

Gargi DasguPta, R.A.M. Brown and Santosh Rawat (2004), "Performance management and appraisal system: HR tools for global competitiveness/ T.V.Rao".

Ken Langdon and Christina Osborne (2004): "Staff performance review," General Publishing House of Ho Chi Minh City.

Lloyd, N. C. (1990), "Performance Appraisal - Theory and Pratice”, The University of Queensland, Australia OECD (2005), "Performance - Related Pay Policies for Government Employees”, OECD Publishing, Paris. 